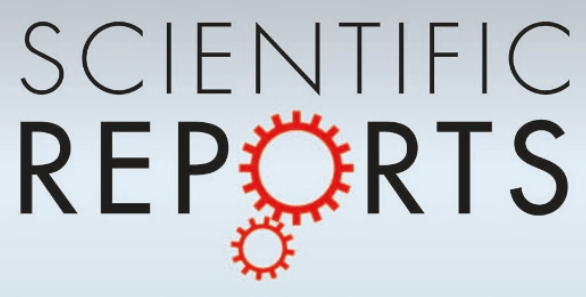

OPEN

SUBJECT AREAS:

BIOGEOCHEMISTRY

CLIMATE CHANGE

CLIMATE-CHANGE POLICY

ENVIRONMENTAL SCIENCES

Received

16 April 2013

Accepted

24 June 2013

Published

12 July 2013

Correspondence and requests for materials should be addressed to

D.C. (delichen@ unimelb.edu.au)

\section{The potential for carbon sequestration in Australian agricultural soils is technically and economically limited}

\author{
Shu Kee Lam, Deli Chen, Arvin R. Mosier \& Richard Roush
}

Melbourne School of Land and Environment, The University of Melbourne, Victoria 3010, Australia.

Concerns about increasing concentrations of greenhouse gases in the atmosphere, primarily carbon dioxide $\left(\mathrm{CO}_{2}\right)$, have raised worldwide interest in the potential of agricultural soils to be carbon (C) sinks. In Australia, studies that have quantified the effects of improved management practices in croplands on soil C have generally been inconclusive and contradictory for different soil depths and durations of the management changes. We therefore quantitatively synthesised the results of Australian studies using meta-analytic techniques to assess the technical and economic feasibility of increasing the soil C stock by improved management practices. Our results indicate that the potential of these improved practices to store $\mathrm{C}$ is limited to the surface $0-10 \mathrm{~cm}$ of soil and diminishes with time. None of these widely adopted practices is currently financially attractive under Australia's new legislation known as the Carbon Farming Initiative.

lobally, soils are estimated to contain 1500 Pg of soil organic carbon (C) to a depth of $1 \mathrm{~m}$, approximately double the amount of $\mathrm{C}$ in the atmosphere ${ }^{1}$. Around $160 \mathrm{Pg}$ of organic $\mathrm{C}$ are stored in soils of agricultural croplands in the world ${ }^{1}$. A meta-analysis showed that long-term conversion of native forest and pasture to cropland has reduced soil organic $\mathrm{C}$ stocks by an average of $42 \%$ and $59 \%$, respectively ${ }^{2}$. By adopting improved agricultural management practices, agricultural soils in the world are estimated to have the potential to sequester $0.4-0.8$ Pg C per year ${ }^{3}$.

Improved agricultural management practices such as conversion from conventional to no-till or reduced tillage, residue retention, conversion to permanent pasture, crop rotation and fertiliser application have been shown to increase soil $\mathrm{C}$ in various countries, including Australia ${ }^{4-6}$. However, contradictory results are common in the literature. For example, a meta-analysis based mostly on studies in North America and South America indicated that adoption of no-till did not increase soil C stock down to $40 \mathrm{~cm}$ (ref. 7), and the potential for C accrual following conversion from crop to pasture decreased with soil depth ${ }^{2}$. Carbon sequestration rates under different grassland management practices have been demonstrated to vary substantially over time ${ }^{4}$.

Large and continuous inputs of organic matter are conducive to increasing soil C content ${ }^{8}$. The net primary productivity of most of Australia's agricultural land, which determines the potential C input, is water and nutrient limited'. Soil C concentrations in Australia are inherently low, except for limited areas under higher rainfall along the east coast ${ }^{5}$. The range of soil $\mathrm{C}$ in the upper $1 \mathrm{~m}$ of soil in Australia is $18-447 \mathrm{Mg} \mathrm{ha}^{-1}$, compared to a global value of 30-800 $\mathrm{Mg} \mathrm{ha}^{-1}$ (ref. 8). While the impacts of agricultural management practices on soil C sequestration potential in Australia have been reviewed ${ }^{5,9}$, a quantitative synthesis of the responses of the soil C stock to these practices for a range of soil depths and years of implementation is lacking.

This information is important for assessing the potential of improved management practices to increase $\mathrm{C}$ storage, or reduce $\mathrm{C}$ loss, within soil profiles and over time. Farmers and land managers need this information to determine whether they can earn carbon credits under Australia's Carbon Farming Initiative (CFI), which was launched to create a financial incentive for the adoption of management practices that store soil C permanently (100 years or more) and improve the soil condition and hence its productivity ${ }^{10}$.

The carbon and nitrogen $(\mathrm{N})$ cycles are tightly coupled ${ }^{11}$. The C:N ratio of agricultural soils generally maintains a constant narrow range, with an average of $10: 1^{8}$. Thus, $\mathrm{N}$ is required to stabilise agricultural soil $\mathrm{C}$ accrual ${ }^{6}$. However, the cost of $\mathrm{N}$ for $\mathrm{C}$ storage is often overlooked in assessing the benefit of $\mathrm{C}$ credit earned from improved management practices.

We therefore conducted a meta-analysis of published data on the responses of soil $\mathrm{C}$ to improved agricultural practices, viz. conservation tillage, residue retention, the use of pasture, and fertiliser $\mathrm{N}$ application. The objectives of this analysis were (i) to quantify the changes in soil C concentration and soil C stock under improved 

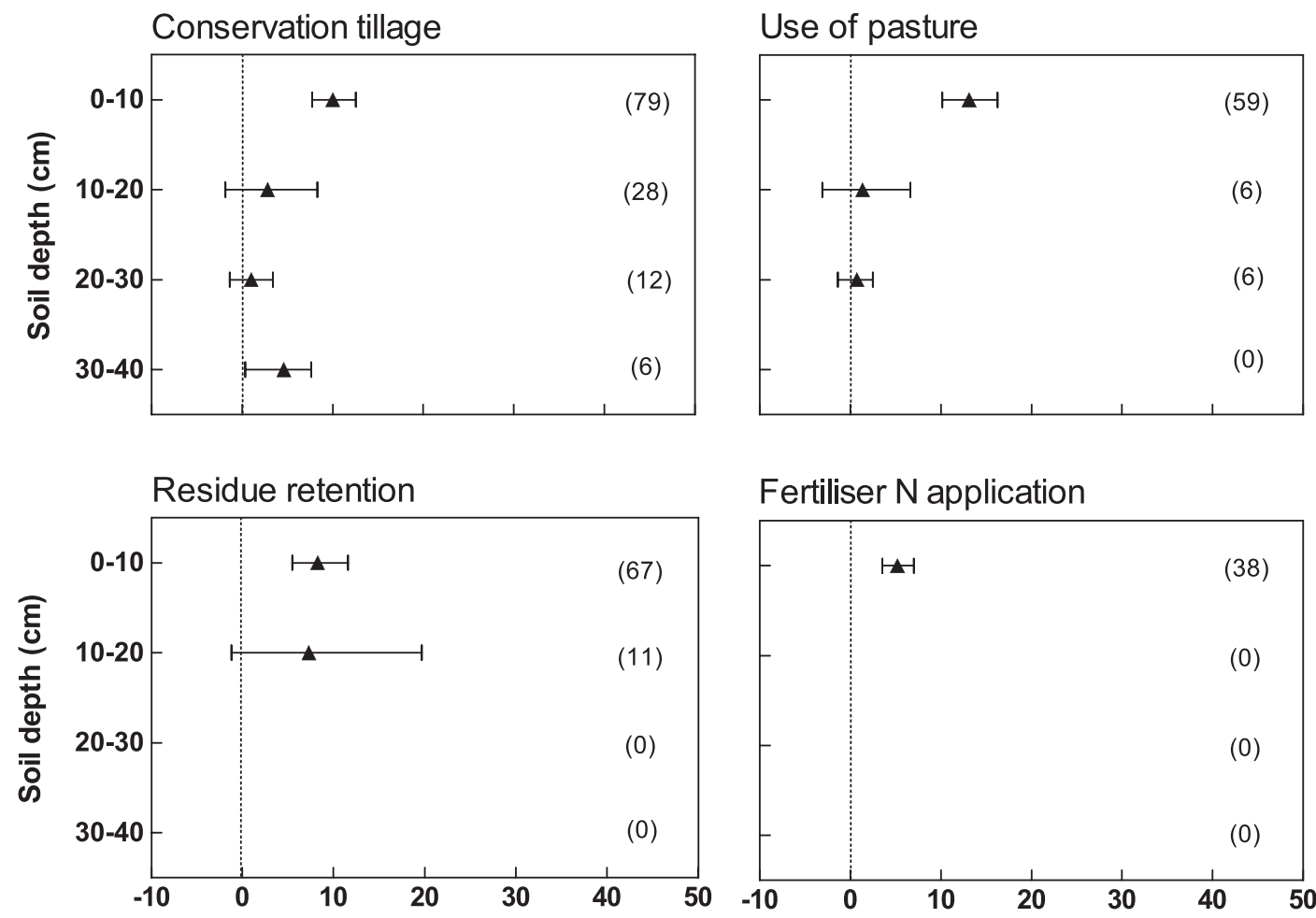

\section{Effect of improved management practice on soil C concentration (\%)}

Figure $1 \mid$ Effect of improved management practices on soil C concentration at various soil depths. Means and $95 \%$ confidence intervals are depicted. Numbers of experimental observations are in parentheses. The database of the meta-analyses can be found as Supplementary Tables S1-S4 online.

management practices, with respect to soil depth and management duration; and (ii) to provide a simple assessment of the economic feasibility of these practices.

\section{Results}

Effect of improved management practices on soil $\mathrm{C}$ at various soil depths. Soil C concentration in the surface soil layer $(0-10 \mathrm{~cm})$ was significantly greater under conservation tillage (by 10\%), residue retention (by $8 \%$ ), the use of pasture (by 13\%) and fertiliser $\mathrm{N}$ application (by 7\%), when compared to control treatments (Fig. 1). Soil $\mathrm{C}$ stock in surface soil $(0-10 \mathrm{~cm})$ was higher under these management treatments than in the untreated controls. The relative gain in soil $\mathrm{C}$ stock in this surface layer was in the order of: pasture use $\left(140 \mathrm{~kg} \mathrm{C} \mathrm{ha}^{-1}\right.$ year $\left.^{-1}\right)>$ conservation tillage (139 $\mathrm{kg} \mathrm{C}$ $\mathrm{ha}^{-1}$ year $\left.^{-1}\right)>$ residue retention $\left(62 \mathrm{~kg} \mathrm{C} \mathrm{ha}^{-1}\right.$ year $\left.^{-1}\right)>$ fertiliser $\mathrm{N}$ application (47 kg C ha ${ }^{-1}$ year $^{-1}$ ) (Table 1). Neither soil C concentration or soil $\mathrm{C}$ stock was significantly increased by these management in soil deeper than $10 \mathrm{~cm}$ (Fig. 1; Table 1).

Effect of improved management practices on soil C under different experimental durations. The four management practices significantly increased soil $\mathrm{C}$ concentration for at least 20 years after the treatments began (Fig. 2). These increases were averaged across soil depths, but were reflective of the changes occurring mostly in the 0 $10 \mathrm{~cm}$ layer (Fig. 1). While the effects on soil $\mathrm{C}$ concentration of residue retention (2-10\%) and fertiliser $\mathrm{N}$ application (3-7\%) decreased with time, those for conservation tillage (7-10\%) and pasture use (10-13\%) were sustained longer (Fig. 2). The annual relative gain in soil $\mathrm{C}$ stock was greatest during the first 10 years after implementation of improved management treatments, when the increases were in the order of: conservation tillage $(150 \mathrm{~kg} \mathrm{C}$ $\mathrm{ha}^{-1}$ year $\left.^{-1}\right)>$ residue retention $\left(147 \mathrm{~kg} \mathrm{C} \mathrm{ha}^{-1}\right.$ year $\left.^{-1}\right)>$ pasture use $\left(132 \mathrm{~kg} \mathrm{C} \mathrm{ha}^{-1}\right.$ year $\left.^{-1}\right)>$ fertiliser $\mathrm{N}$ application $\left(67 \mathrm{~kg} \mathrm{C} \mathrm{ha}^{-1}\right.$ year $^{-1}$ ) (Table 2). These increases correspond to a soil C gain of 247$552 \mathrm{~kg} \mathrm{CO}$-equivalent $\left(\mathrm{CO}_{2}\right.$-e $)$ ha $^{-1}$ year ${ }^{-1}$ during the first 10 years of implementation of the improved management practices (Table 2).

Economic assessment. The relative soil $\mathrm{C}$ gain represents a carbon credit of AUD $1.8 \mathrm{ha}^{-1}$ year $^{-1}$ by practising conservation tillage,

Table 1 | Effect of agricultural management practices on soil $\mathrm{C}$ stock at various soil depths. The database of the meta-analyses can be found as Supplementary Tables S1-S4 online

\begin{tabular}{lcc} 
& \multicolumn{2}{c}{ Relative change in C stock $\left(\mathrm{kg} \mathrm{C} \mathrm{ha}^{-1}\right.$ year $^{-1}$ ) } \\
\cline { 2 - 3 } Soil depth $(\mathrm{cm})$ & Mean & $95 \% \mathrm{Cl}$ \\
\hline Conservation tillage & 139 & 101 to 184 \\
$0-10$ & 24 & -27 to 75 \\
$10-20$ & 21 & 5 to 35 \\
$20-30$ & 36 & 0 to 80 \\
$30-40$ & & \\
Residue retention & 62 & 31 to 91 \\
$0-10$ & 30 & -5 to 71 \\
$10-20$ & 2 & -9 to 11 \\
$20-30$ & $\mathrm{NA}$ & $\mathrm{NA}$ \\
$30-40$ & 140 & 69 to 250 \\
Use of pasture & -18 & -153 to 128 \\
$0-10$ & 14 & -60 to 65 \\
$10-20$ & $\mathrm{NA}$ & $\mathrm{NA}$ \\
$20-30$ & & \\
$30-40$ & 47 & 18 to 66 \\
Fertiliser N application & 11 & 1 to 20 \\
$0-10$ & 2 & -8 to 11 \\
$10-20$ & $\mathrm{NA}$ & $\mathrm{NA}$ \\
$20-30$ & & \\
$30-40$ & &
\end{tabular}



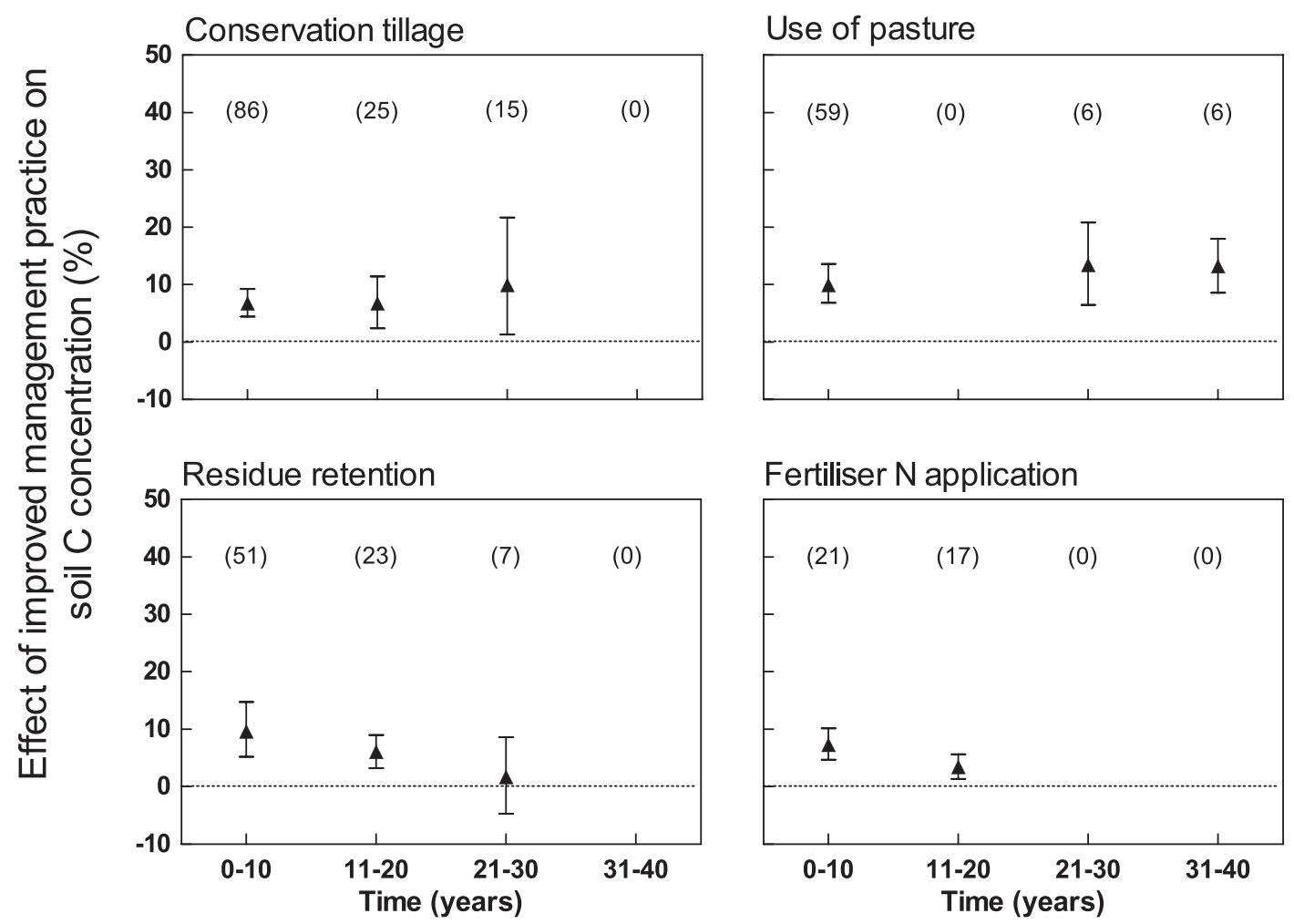

Figure $2 \mid$ Effect of improved management practices on soil $\mathrm{C}$ concentration under different experimental durations. Means and $95 \%$ confidence intervals are depicted. Numbers of experimental observations are in parentheses. The database of the meta-analyses can be found as Supplementary Tables S1-S4 online.

Table 2 | Effect of agricultural management practices on soil $\mathrm{C}$ stock, $\mathrm{C}$ credit and financial returns under different experimental durations. The database of the meta-analyses can be found as Supplementary Tables S1-S4 online

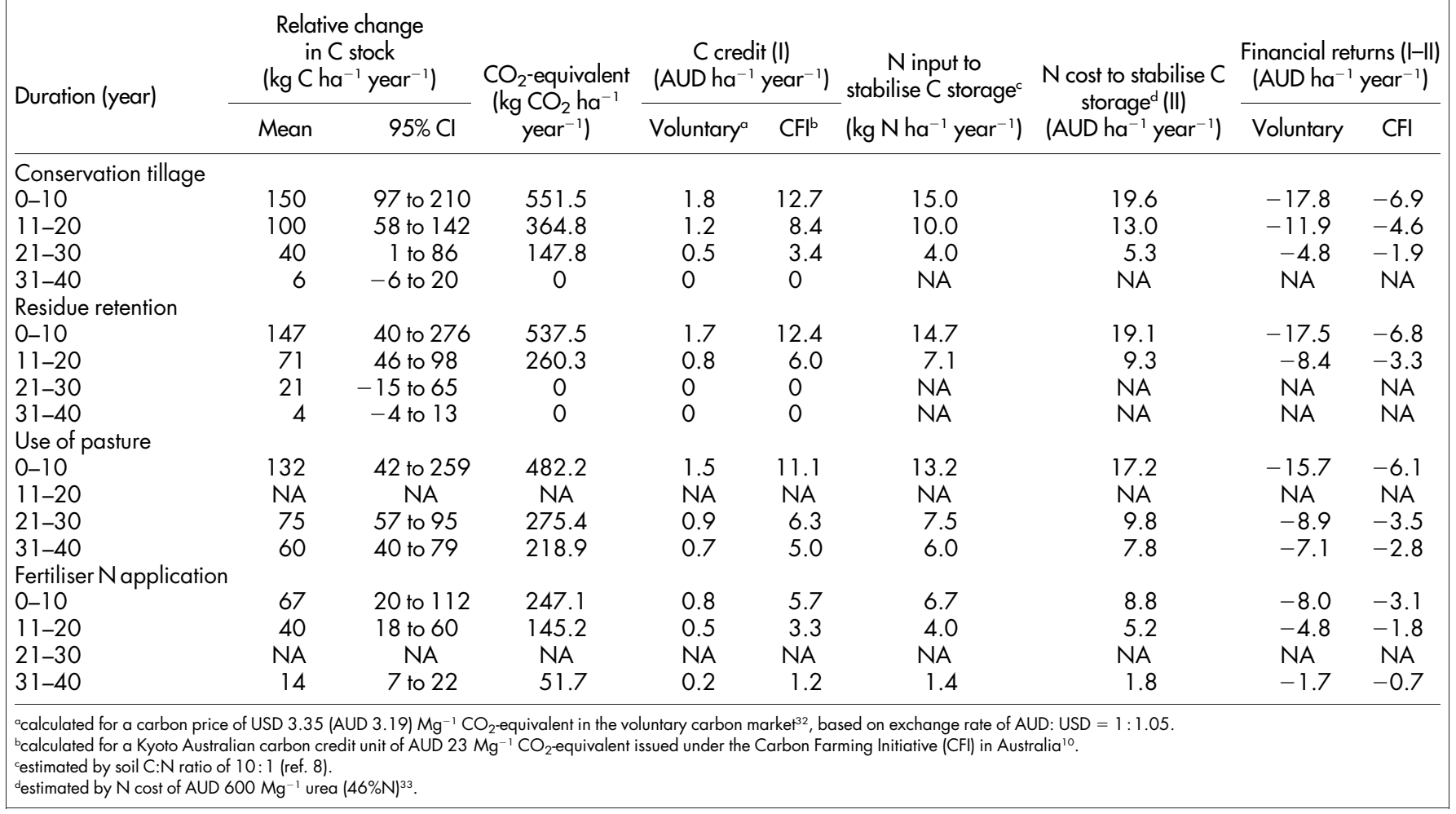


AUD 1.7 $\mathrm{ha}^{-1}$ year $^{-1}$ for residue retention, AUD $1.5 \mathrm{ha}^{-1}$ year $^{-1}$ for the use of pasture, and AUD $0.8 \mathrm{ha}^{-1}$ year $^{-1}$ for fertiliser $\mathrm{N}$ application, during the first 10 years of a management change (Table 2). When the cost of $\mathrm{N}$ to stabilise $\mathrm{C}$ storage was considered, the financial loss based on the $\mathrm{C}$ price in the voluntary carbon market was AUD $17.8 \mathrm{ha}^{-1}$ year $^{-1}$ for conservation tillage, AUD $17.5 \mathrm{ha}^{-1}$ year $^{-1}$ for residue retention, AUD $15.7 \mathrm{ha}^{-1}$ year $^{-1}$ for pasture use, and AUD $8.0 \mathrm{ha}^{-1}$ year $^{-1}$ for fertiliser $\mathrm{N}$ application (Table 2). Based on the CFI, the financial loss was reduced to AUD 6.9, 6.8, 6.1 and $3.1 \mathrm{ha}^{-1}$ year $^{-1}$ correspondingly (Table 2 ).

\section{Discussion}

Based on the available field studies that covered a wide range of soil and climatic conditions across Australia, our results suggest that soil at $0-10 \mathrm{~cm}$ depth is the most responsive to the targeted management practices in Australia's cropped soils. Increases in soil C as a result of these management practices have been attributed to enhanced biomass (above- and below-ground) production, litterfall and hence return of residues to the soil, and also to improved soil aggregation that protects the C compounds from rapid decomposition ${ }^{4,6,12}$. However, the small increases $(7-13 \%)$ in the $\mathrm{C}$ concentration in the surface layer of Australian agricultural soils may not be technically credible due to sampling errors, spatial variability and uncertainties associated with measurement and analysis ${ }^{13}$. The positive management effects on soil $\mathrm{C}$ concentration or $\mathrm{C}$ stock were not detectable in soil deeper than $10 \mathrm{~cm}$ (Fig. 1; Table 1). This result is not unique to Australian cropping systems. For example, in studies comparing conservation tillage with conventional tillage in other countries, it has been shown that soil $\mathrm{C}$ may increase only in the surface $10 \mathrm{~cm}$ of the soil, and remain unchanged or even decrease in deeper layers ${ }^{7,14}$.

Carbon accumulation can be increased in the surface $0-10 \mathrm{~cm}$ of soil, but that is also the layer from which it can be most readily lost from Australian agricultural soils ${ }^{5}$, and the management-induced increases of soil $\mathrm{C}$ in this surface layer are very vulnerable to environmental and management pressures ${ }^{9}$. It is therefore necessary to examine whether an agricultural practice sustains surface soil C over time. This is important because the intent of Australia's CFI is to encourage farmers and land managers to use an approved methodology that enables permanent storage of soil C $(100+\text { years })^{10}$. However, we found that the relative soil $\mathrm{C}$ gain in Australian cropping systems decreased with time, regardless of agricultural practices (Table 2). Moreover, soil organic $\mathrm{C}$ in many Australian cropping soils is not in state of $\mathrm{C}$ equilibrium, and the soils are continuing to lose $\mathrm{C}^{15}$. The observed relative $\mathrm{C}$ gain under improved management treatments might therefore have resulted from a reduced or discontinued soil C loss instead of real C accrual ${ }^{15}$.

In terms of sustainability, the use of pasture outperformed the other practices after 31-40 years (Table 2). This highlights the potential use of pasture in $\mathrm{C}$ sequestration in Australian agriculture, for at least 40 years. However, at least three problems must be considered with increased pasture use, especially permanent pasture, in Australia: (i) increased methane emissions for ruminant animals grazing those pastures, (ii) the extra demand for irrigation water to maintain those pastures (if they are to be effective in storing more soil $\mathrm{C}$ ), and (iii) the less efficient use of solar radiation per hectare in producing food from animals compared to food from crops.

When the cost of $\mathrm{N}$ to stabilise $\mathrm{C}$ accrual was considered, we estimated that none of the four management practices resulted in any net profit based on the recent $\mathrm{C}$ trading price of AUD $3.19 \mathrm{Mg}^{-1}$ $\mathrm{CO}_{2}$-e in the voluntary market, but a loss of AUD 8-18 ha ${ }^{-1}$ year $^{-1}$ for the first 10 years of implementation of the practice (Table 2). The loss was reduced to AUD 3-7 $\mathrm{ha}^{-1}$ year $^{-1}$ under the CFI in Australia (currently at AUD $23 \mathrm{Mg}^{-1} \mathrm{CO}_{2}-\mathrm{e}$ ). The minimum $\mathrm{C}$ price required for a net profit was estimated to be AUD $36 \mathrm{Mg}^{-1} \mathrm{CO}_{2}$-e. These results indicate that current agricultural management options and the current value of conserved $\mathrm{C}$ are not economically viable. More importantly, for a carbon trading scheme to be credible, change in soil C has to be verifiably measured or modelled cost-effectively at the farm scale ${ }^{13}$

In terms of benefits to the environment, based on an area of approximately $100 \mathrm{M}$ ha of managed cropland and modified pasture in Australia in 2006 (ref. 16), we estimate that the gain in $\mathrm{CO}_{2}$-e equates to $4.6-10.3 \%$ of total national greenhouse gas (GHG) emissions in the same year of $533.1 \mathrm{Tg} \mathrm{CO}_{2}-\mathrm{e}^{17}$. This estimate assumes 100 percent take-up of the improved practices and does not consider the potential impact of these practices on emissions of methane from grazing animals and nitrous oxide from additional $\mathrm{N}$ fertiliser use ${ }^{18-21}$. While the effects of improved management practices on soil $\mathrm{C}$ stock vary with temperature and rainfall ${ }^{5}$, scientific knowledge of the capacity of the soil to store $\mathrm{C}$ under future climates, such as warmer and drier conditions and higher atmospheric $\mathrm{CO}_{2}$ levels ${ }^{22-24}$, is insufficient for Australian cropping systems.

Our analysis shows that improved management practices (conservation tillage, residue retention, the use of pasture or fertiliser $\mathrm{N}$ application) increased soil $\mathrm{C}$ by $0.05-0.15 \mathrm{Mg} \mathrm{C} \mathrm{ha}^{-1}$ year $^{-1}$ only in the surface $10 \mathrm{~cm}$ of Australian croplands. The effects were more pronounced during the first 10 years of implementation of improved management practices.

Because of the technical uncertainty in measuring small soil $\mathrm{C}$ changes, and the higher cost of stabilising any gain in soil $\mathrm{C}$ compared with the $\mathrm{C}$ credit earned, carbon sequestration in Australian agricultural soils as a means of offsetting a significant part of the national GHG emissions is technically limited and economically nonviable at the present time. These results have major implications for improvement in the measurement and modelling of soil $\mathrm{C}$ changes at the field scale, and enactment of carbon reduction legislations in Australia and other parts of the world.

\section{Methods}

Database compilation. This meta-analysis is based on studies (see Supplementary Notes online) of the effects of agricultural land management practices (conservation tillage, residue retention, the use of pasture, and $\mathrm{N}$ fertilisation) on soil $\mathrm{C}$ concentration $(\% \mathrm{C})$ and $\mathrm{C}$ stock $\left(\mathrm{kg} \mathrm{C} \mathrm{ha}^{-1}\right)$ in Australian cropping systems published between 1984 and December 2012. We performed extensive keyword searches of several databases (Web of Science, CAB Abstracts, Scopus, Agricola and Agriculture and Natural Resources Index), and by examining the reference lists of cited references. The search terms are listed in Supplementary Notes online. Original data were extracted from tables whereas data values presented in figures were obtained using digitizing software.

The following criteria were set for a study to be included in the analysis. First, the sample sizes and means of soil C concentrations or stocks had to be reported for control and treatment plots. Second, treatments were applied at the same farm site throughout the experimental period, i.e. paired-site studies or surveys were excluded. Third, the study must have been conducted under field conditions for at least three consecutive years. For multiple observations at any one site over time, individual observations were selected at intervals of at least every third year. The duration of an experiment was considered as the number of years after the commencement of a treatment. Conservation tillage encompassed no-till and reduced tillage. Residue retention comprised the incorporation of residues and surface retention. The use of pasture included conversion of cropped land to pasture and the incorporation of pasture into a rotation.

Because the soil $C$ stock is an amount of $C$ in a mass of soil in a defined area (1 ha) to a defined depth (commonly $30 \mathrm{~cm}$ ), $\mathrm{C}$ concentration must be multiplied by the dry bulk density (BD) to obtain the soil C stock $\left(\mathrm{kg} \mathrm{ha}^{-1}\right)$. Hence when not reported, soil C stock was calculated by multiplying the $\% \mathrm{C}$ values for each soil depth interval by its $\mathrm{BD}$ and the depth increment. In experiments where $\mathrm{BD}$ was not provided, a pedotransfer function was used to estimate BD. For the studies included in this metaanalysis, we considered two published pedotransfer functions for the estimation of $\mathrm{BD}$ by comparing the regression between measured and estimated $\mathrm{BD}$ values. The two functions were $\mathrm{BD}=1.66-0.308(\mathrm{OC})^{0.5}$ (equation $\left.(1)^{25}\right)$ and $\mathrm{BD}=1.398-0.0047$ (\%Clay) -0.042 (\%OC) (equation (2) ${ }^{26}$ ), where the $\mathrm{BD}$ units were $\mathrm{Mg} \mathrm{m}^{-3}$ and $\mathrm{OC}=$ organic carbon (\%). Based on equation (2), the regression coefficient between measured and estimated BD values was $0.64(p<0.001)$, whereas that based on equation (1) was $0.32(p<0.001)$. We therefore based our estimation of BD on equation (2).

Ideally, the soil $\mathrm{C}$ stock for treatments and controls should be compared on an equivalent mass, rather than a fixed depth basis, because of the changes in BD that may occur under different management practices ${ }^{27}$. In our study, soil depth was not adjusted to account for changes, if any, in BD associated with changes in management practices unless the authors of the study had already done so. Not adjusting soil depth 
may in some cases result in a small error in the estimate of the management effects on soil C stocks per unit land area ${ }^{28}$.

The database of the meta-analyses is in Supplementary Tables S1-S4 online. The dataset was compiled from 56 studies with 435 direct comparisons, including 172 comparisons for the effects of conservation tillage, 116 for residue retention, 83 for the use of pasture and 64 for fertiliser $\mathrm{N}$ application. The potential patterns of variation in the effects of various management practices were also assessed by including categorical variables in the meta-analysis models. These variables included experimental duration $(0-10,11-20,21-30$ and 31-40 years) and soil depth $(0-10,10-20,20-30$ and $30-40 \mathrm{~cm}$ ). Soil sampling depths varied between studies. For studies in which the sampling depths did not match the defined categories, each data point for $\mathrm{C}$ concentration was categorised as the average depth of the soil layer from which it was collected $^{14}$. Soil C stock data were included only if the sampling depth matched the defined categories.

Meta-analysis. We used the natural $\log$ of the response ratio $\left(r=\bar{x}_{t} / \bar{x}_{c}\right.$, where $\bar{x}_{t}$ and $\bar{x}_{c}$ are the means of the treatment and control groups, respectively) ${ }^{29}$ as a metric for the analysis of treatment effects on soil $\mathrm{C}$ concentration. These results are reported as the percentage change under treatment effects $((r-1) \times 100)$. Negative percentage changes indicate a decrease in soil $\mathrm{C}$ compared with the control and positive values indicate an increase due to an improved management practice. The effect of management practices on the rate of change in the soil $\mathrm{C}$ stock relative to the control was expressed as $U\left(\mathrm{~kg} \mathrm{Cha}^{-1}\right.$ year $\left.^{-1}\right)=$ (amount of $\mathrm{C}$ in treatment plot amount of $\mathrm{C}$ in control plot)/experimental duration.

Effect sizes reported in previous meta-analyses on soil C storage were weighted by the inverse of the pooled variance ${ }^{6}$, replication ${ }^{23}$ or unweighted ${ }^{2}$. The studies collected in our database did not always include published variances. In addition, the variancebased weighting function could result in extreme weights for some studies, while weighting by replication could yield less extreme weights ${ }^{30}$. Therefore our analysis was performed on effect sizes weighted by a function of sample size using:

$$
\text { weight }=\left(n_{\mathrm{c}} \times n_{\mathrm{t}}\right) /\left(n_{\mathrm{c}}+n_{\mathrm{t}}\right),
$$

where $n_{\mathrm{c}}$ and $n_{\mathrm{t}}$ are the number of replicates of the control and treatment groups, respectively ${ }^{30}$.

Mean effect sizes and $95 \%$ confidence intervals were generated by bootstrapping (4,999 iterations) using MetaWin 2.1 ${ }^{31}$. A fixed-effects model or a mixed-effects model is technically not applicable for non-parametric meta-analytic procedures based on weighting by replication. However, to perform correct bootstrapping using MetaWin a fixed-effects model had to be selected. The effects of agricultural management practices were considered significant if the confidence intervals did not overlap with zero.

Economic assessment. We performed an economic assessment of the improved management practices based on the C price of USD 3.35 (AUD 3.19) $\mathrm{Mg}^{-1} \mathrm{CO}_{2}$-e in the voluntary carbon market in 2008 (ref. 32) or Kyoto Australian carbon credit unit at AUD $23 \mathrm{Mg}^{-1} \mathrm{CO}_{2}$-e in 2013 (ref. 10), a C:N ratio of $10: 1$ across agricultural soils ${ }^{8}$, and the cost of urea $(46 \% \mathrm{~N})$ at AUD $600 \mathrm{Mg}^{-1}$ (ref. 33). These estimates exclude any increase in $\mathrm{N}$ fertiliser cost passed on to the landholder, which is incurred by the manufacturer having to pay the mandatory $\mathrm{C}$ price (currently AUD $23 \mathrm{Mg}^{-1} \mathrm{CO}_{2}$ $\mathrm{e}^{10}$ ) associated with GHG emissions during production. The costs of other nutrients such as phosphorus and sulphur to match $C$ gain are not included, nor any of the compliance costs such as reporting and auditing associated with participation in the CFI.

1. Stockmann, U. et al. The knowns, known unknowns and unknowns of sequestration of soil organic carbon. Agric. Ecosyst. Environ. 164, 80-99 (2013).

2. Guo, L. B. \& Gifford, R. M. Soil carbon stocks and land use change: a meta analysis. Glob. Change Biol. 8, 345-360 (2002).

3. Lal, R. Soil carbon sequestration impacts on global climate change and food security. Science 304, 1623-1627 (2004).

4. Conant, R. T., Paustian, K. \& Elliott, E. T. Grassland management and conversion into grassland: effects on soil carbon. Ecol. Appl. 11, 343-355 (2001).

5. Luo, Z., Wang, E. \& Sun, O. J. Soil carbon change and its responses to agricultural practices in Australian agro-ecosystems: a review and synthesis. Geoderma 155, 211-223 (2010).

6. Lu, M. et al. Minor stimulation of soil carbon storage by nitrogen addition: a metaanalysis. Agric. Ecosyst. Environ. 140, 234-244 (2011).

7. Luo, Z., Wang, E. \& Sun, O. J. Can no-tillage stimulate carbon sequestration in agricultural soils? A meta-analysis of paired experiments. Agric. Ecosyst. Environ. 139, 224-231 (2010).

8. Carlyle, J. C., Charmley, E., Baldock, J. A., Polglase, P. J. \& Keating, B. in Adapting Agriculture to Climate Change: Preparing Australian Agriculture, Forestry and Fisheries for the Future (eds Stokes, C. \& Howden, M.) 229-244 (CSIRO Publishing, 2010).

9. Sanderman, J., Farquharson, R. \& Baldock, J. Soil Carbon Sequestration Potential: a Review for Australian Agriculture (CSIRO Publishing, 2010).

10. Department of Climate Change and Energy Efficiency. The Carbon Farming Initiative Handbook Version 1.0 (Australian Department of Climate Change and Energy Efficiency, 2012), accessed 10 June 2013 at http://
www.climatechange.gov.au/sites/climatechange/files/files/reducing-carbon/CFIHandbook-20120403-PDF.pdf.

11. Gruber, N. \& Galloway, J. N. An earth-system perspective of the global nitrogen cycle. Nature 45, 293-296 (2008).

12. Six, J., Paustian, K., Elliott, E. T. \& Combrink, C. Soil structure and organic matter: I. Distribution of aggregate-size classes and aggregate-associated carbon. Soil Sci. Soc. Am. J. 64, 681-689 (2000).

13. Walcott, J., Bruce, S. \& Sims, J. Soil Carbon for Carbon Sequestration and Trading: a Review of Issues for Agriculture and Forestry (Australian Bureau of Rural Sciences, 2009).

14. Angers, D. A. \& Eriksen-Hamel, N. S. Full-inversion tillage and organic carbon distribution in soil profiles: a meta-analysis. Soil Sci. Soc. Am. J. 72, 1370-1374 (2008).

15. Sanderman, J. \& Baldock, J. A. Accounting for soil carbon sequestration in national inventories: a soil scientist's perspective. Environ. Res. Lett. 5, 034003 (2010).

16. Bureau of Rural Sciences. Land Use of Australia Version 4, 2005-06 data (Australian Bureau of Rural Sciences, 2010).

17. Department of Climate Change and Energy Efficiency. National Inventory Report 2009 Australian National Greenhouse Accounts Volume 3 (Australian Department of Climate Change and Energy Efficiency, 2011).

18. Barclay, A. Farming carbon. ECOS 156, 24-26 (CSIRO Publishing 2010).

19. Liu, L. \& Greaver, T. L. A review of nitrogen enrichment effects on three biogenic GHGs: the $\mathrm{CO}_{2}$ sink may be largely offset by stimulated $\mathrm{N}_{2} \mathrm{O}$ and $\mathrm{CH}_{4}$ emission. Ecol. Lett. 12, 1103-1117 (2009).

20. Wang, W., Dalal, R. C., Reeves, S. H., Butterbach-Bahl, K. \& Kiese, R. Greenhouse gas fluxes from an Australian subtropical cropland under long-term contrasting management regimes. Glob. Change Biol. 17, 3089-3101 (2011).

21. van Kessel, C. et al. Climate, duration, and $\mathrm{N}$ placement determine $\mathrm{N}_{2} \mathrm{O}$ emissions in reduced tillage systems: a meta-analysis. Glob. Change Biol. 19, 33-44 (2012).

22. Conant, R. T. et al. Temperature and soil organic matter decomposition rates synthesis of current knowledge and a way forward. Glob. Change Biol. 17, 3392-3404 (2011).

23. Hungate, B. A. et al. Assessing the effect of elevated carbon dioxide on soil carbon: a comparison of four meta-analyses. Glob. Change Biol. 15, 2020-2034 (2009).

24. Schils, R. et al. Review of Existing Information on the Interrelations between Soil and Climate Change (ClimSoil). Final Report (European Commission, 2008).

25. Alexander, E. B. Bulk densities of California soils in relation to other soil properties. Soil Sci. Soc. Am. J. 44, 689-692 (1980).

26. Bernoux, M., Arrouays, D., Cerri, C., Volkoff, B. \& Jolivet, C. Bulk densities of Brazilian Amazon soils related to other soil properties. Soil Sci. Soc. Am. J. 62, 743-749 (1988).

27. Powlson, D. S., Whitmore, A. P. \& Goulding, K. W. T. Soil carbon sequestration to mitigate climate change: a critical re-examination to identify the true and the false. Eur. J. Soil Sci. 62, 42-55 (2011)

28. Post, W. M. \& Kwon, K. C. Soil carbon sequestration and land-use change: processes and potential. Glob. Change Biol. 6, 317-327 (2000).

29. Hedges, L. V., Gurevitch, J. \& Curtis, P. S. The meta-analysis of response ratios in experimental ecology. Ecology 80, 1150-1156 (1999).

30. van Groenigen, K. J., Osenberg, C. W. \& Hungate, B. A. Increased soil emissions of potent greenhouse gases under increased atmospheric $\mathrm{CO}_{2}$. Nature 475, 214-216 (2011).

31. Rosenberg, M. S., Adams, D. C. \& Gurevitch, J. MetaWin: Statistical Software for Meta-Analysis Version 2 (Sinauer Associates Inc., 2000).

32. Hamilton, K., Sjardin, M., Shapiro, A. \& Marcello, T. Fortifying the Foundation: State of the Voluntary Carbon Markets 2009. (Ecosystem Marketplace and New Carbon Finance, 2009), accessed 28 December 2012 at http:// ecosystemmarketplace.com/documents/cms_documents/ StateOfTheVoluntaryCarbonMarkets_2009.pdf.

33. Mulvany, J. Managing Your Farm Business in a Variable Climate, Riding the Diary Roller Coaster Forum (Australian Department of Agriculture, Forestry \& Fisheries and Dairy Australia, 2011), accessed 19 November 2012 at http:// frds.dairyaustralia.com.au/wp-content/uploads/2012/01/WP956-JohnMulvaney-riding-the-rollercoaster.pdf.

\section{Acknowledgements}

We wish to thank Emeritus Professor Robert White and Dr Ian Willett for valuable comments on our manuscript, Dr. Kees Jan van Groenigen for assistance in meta-analytic procedures, and the authors who provided information for the construction of the database. This work was supported by Australian Research Council, Department of Agriculture, Fisheries and Forestry and Dean's strategic research fund of our School.

\section{Author contributions}

R.R. and D.C. initiated the concept of the study. R.R., D.C., A.R.M. and S.K.L. designed the investigation. S.K.L. and D.C. contributed to data extraction from the literature and the construction of the database. S.K.L., D.C. and A.R.M. performed the statistical analyses. All authors were involved in writing the paper. 


\section{Additional information}

Supplementary information accompanies this paper at http://www.nature.com/ scientificreports

Competing financial interests: The authors declare no competing financial interests.
How to cite this article: Lam, S.K., Chen, D., Mosier, A.R. \& Roush, R. The potential for carbon sequestration in Australian agricultural soils is technically and economically limited. Sci. Rep. 3, 2179; DOI:10.1038/srep02179 (2013).

(c) (1) $(-)$ This work is licensed under a Creative Commons Attributioncc. visit http://creativecommons.org/licenses/by-nc-nd/3.0 